\title{
The Mediating Role of Psychological Resilience in the Relationship between Coping Humor and Psychological Well-being
}

\section{Mizah Yoluyla Başa Çıkma ile Psikolojik İyi Oluş Arasındaki İlişkide Psikolojik Dayanıklılığın Aracı Rolü}

\author{
Zöhre KAYA*
}

\author{
Ferdi YAĞAN ${ }^{* *}$
}

Received: 08 June 2021

Research Article

Accepted: 23 December 2021

ABSTRACT: This study examines the mediating role of psychological resilience in the relationship between psychological counselors' use of coping humor and psychological well-being through structural equation modeling. Research participants comprise 228 psychological counselors between the ages of 23 and 52, among which 130 are female and 98 are male. A correlational research model is used in the research as one of the quantitative research methods. Data is collected through the scales of Coping Humor, Psychological Well-Being, and Psychological Resilience. Data is analyzed through $t$-test, Pearson product-moment correlation and structural equation modeling. Findings demonstrate that there is positively significant correlation between coping humor, psychological well-being, and psychological resilience. Moreover, coping humor significantly predicts psychological well-being positively whilst psychological resilience remains a partial mediating variable in this relationship. Findings show that the conceptual model developed for relationships between coping humor, psychological well-being, and psychological resilience is statistically supported.

Keywords: Coping humor, psychological well-being, psychological resilience, psychological counselor.

ÖZ: Bu araştırmada, psikolojik danışmanlarda mizah yoluyla başa çıkma ile psikolojik iyi oluş arasındaki ilişkide psikolojik dayanıklılığın aracı rolünün yapısal eşitlik modellemesi ile incelenmesi amaçlanmıştır. Araştırmada nicel araştırma yöntemlerinden ilişkisel tarama modeli kullanılmışır. Araştırmanın katılımcıları yaşları 23 ile 52 arasında değişen 130 kadın ve 98 erkek olmak üzere toplam 228 psikolojik danışmandan oluşturmaktadır. Araştırma verilerinin toplanmasında, Mizah Yoluyla Başa Çıkma, Psikolojik İyi Oluş ve Psikolojik Dayanıklılık ölçekleri kullanılmıştır. Araştırmadan elde edilen veriler, $t$-testi, Pearson momentler çarpım korelasyonu ve yapısal eşitlik modellemesi ile analiz edilmiştir. Araştırmadan elde edilen bulgulara göre, mizah yoluyla başa çıkma, psikolojik iyi oluş ve psikolojik dayanıklılık arasında pozitif yönde anlamlı ilişkiler bulunmaktadır. Ayrıca, mizah yoluyla başa çıkmanın psikolojik iyi oluşu pozitif yönde ve anlamlı bir şekilde yordadı̆̆ı, psikolojik dayanıklılığın ise bu ilişkide kısmi aracı değişken olarak yer aldığı görülmüştür. Araştırma sonuçları, mizah yoluyla başa çıkma, psikolojik iyi oluş ve psikolojik dayanıklılık arasındaki ilişkilere yönelik kurulan kavramsal modelin istatistiksel olarak desteklendiğini ortaya koymuştur.

Anahtar kelimeler: Mizah yoluyla başa çıkma, psikolojik iyi oluş, psikolojik dayanıklılık, psikolojik danışman.

* Corresponding Author: PhD, Van Yüzüncü Y1l University Faculty of Education, Van, Turkey, zohrekaya@yyu.edu.tr, https://orcid.org/0000-0001-9211-3632

** Psychological Counselor, Ministry of National Education, Hakkari, Turkey, yaganferdi20@gmail.com; https://orcid.org/0000-0002-6862-1288

\section{Citation Information}

Kaya, Z., \& Yağan, F. (2022). The mediating role of psychological resilience in the relationship between coping humor and psychological well-being. Kuramsal Eğitimbilim Dergisi [Journal of Theoretical Educational Science], 15(1), 146-168. 
Detriments of centenary wars, massacres, and other traumatic incidents affecting human beings have urged scientists to study how psychological well-being and human dignity would improve. The discipline of psychology, in particular, has intensified its focus on curing mental illness that people have experienced after the Second World War (Ergün Başak, 2012). They have taken a more conventional approach and used the illness model, which has overlooked two important issues. First, every individual has a latent strength to re-adapt themselves following a bad experience. Second, their positive sides need to be focused on facilitating their re-adaptation (Seligman, 2002). Although the conventional approach was quite effective until the mid-twentieth century, it has also been considered that psychology as a scientific discipline could not be effective in enabling individuals to be more productive and effective by merely focusing on illness and mental illness (Seligman \& Csikszentmihalyi, 2014). Instead, the focus of the discipline has shifted to the impact of psychological well-being on individuals' welfare and productivity (Gable \& Haidt, 2005). Herewith, the emphasis has been placed on positive personality traits and life satisfaction has been of primary importance. All these efforts have resulted in a different approach to be embarked on in psychology that particularly focuses on positive human traits.

This approach, termed positive psychology (Seligman, 2002), preconceives that individuals are innately equipped with positive personality traits and aims to rehabilitate mental disorders and maintain psychological well-being by improving those traits (Bradburn, 1969). Seligman and Csikszentmihalyi (2014) argue that positive psychology is about well-being by focusing on emotions, sensual pleasures, and positive behaviors. On the other hand, Sheldon and King (2001) define positive psychology as a scientific discipline that studies strength and virtue. Moreover, along with positive psychology, not only well-being and resilience but also other concepts such as flow, happiness, creativity (Hefferon \& Boniwell, 2014), welfare, virtue, optimism, forgiveness, hope, curiosity, and humor have gained particular importance and drawn attention for further scientific inquiry in terms of their impact on human beings (Gable \& Haidt, 2005). Therefore, in this study, the effect of humor and psychological resilience on increasing psychological well-being, which is one of the concepts of positive psychology, was found worth investigating.

\section{Literature Review}

Humor has recently gained particular importance in positive psychology (Çiper Kaynar, 2019; Martin, 2001; Yerlikaya, 2009) as it helps cope with stress (Lefcourt, 2001) and is regarded as a tool to generate happiness and to increase positive emotions (Aç1kgöz, 2016). The word humor (mizah) in Turkish has etymological roots within Arabic (Özdolap, 2015). The dictionary of the Turkish Language Association (TLA) defines humor as "teasing someone without hurting their feelings, ridicule" (TLA, 2020). In academic literature, the meaning of the term in use is similar to this definition, and it refers to the act of laughter resulting from ridicule that aims to respond to someone without hurting their feelings (Çiper Kaynar, 2019). Moreover, humor is used to make statements, as well as to make jokes and generate joy (Chauvet \& Hofmeyer, 2007). In short, coping humor can be defined as individuals' reaction to stressful experiences through laughter during and after those experiences are lived, and their 
tendency to ridicule those experiences with others and joke about them (Martin \& Ford, 2007).

It is safe to say that the idea that humor improves resilience against stressful life events and enhances mental health traces far back. Freud (1905) argues that humor, which personality theorists widely refer to, is the healthiest of all coping mechanisms and helps individuals avoid any negative situation without losing the perception of reality. According to Maslow (1954) and Rogers (1961), humor is an important trait of self-realized individuals. Similarly, May (1953) argues that humor helps individuals distance themselves from their problems and re-evaluate them from a different perspective. Allport (1961) states that an advanced sense of humor is the key feature of a mature personality and argues that humor is a significant component of individuals' self-reflexive insights. Differently, Frankl (1984) argues that a sense of humor is an important weapon of the soul in the battle of self-defense and contends that one's ability to laugh at them is quite a significant personal trait. Likewise, Lefcourt and Martin (1986) regard humor as a coping mechanism or strategy, whilst Sherman (1988) considers humor a tool used to develop interpersonal relations and maintain them.

Humor has been an object of inquiry in such disciplines as philosophy, literature, and sociology (Özdolap, 2015). With the advent of positive psychology, it has been a field of interest for the discipline of psychology as well and a widely-studied object of inquiry within it (Yerlikaya, 2009). It is emphasized that humor contributes to psychological and physical well-being (Martin, 2001). It is also known to regulate stress, anxiety, and depression (Lefcourt, 2001; Martin, 1998). Hence, as humor positively affects well-being when used by individuals as a tool to cope with challenges (Alvord et al., 2011; Sat1c1 \& Deniz, 2017), the impact of humor on coping in psychological counselors was considered of interest for research.

Well-being, another important concept for positive psychology, was first defined by Bradburn (1969) as the domination of positive emotions over negative ones. Later, two different models are proposed in regard to well-being. The first of these is "Subjective Well-being" developed by Diener in 1984 (Diener, 2009) and the other is "Psychological Well-being" devised by Ryff (1989). As it is undertaken in this study, psychological well-being is described as the enhanced life quality in a cohesive manner (Keyes \& Annas, 2009). However, subjective well-being is a concept that draws from hedonism and is described as the experience of positive emotions with the satisfaction of desires to enable individuals to arrive at happiness and pleasure (Boniwell, 2012). After the 1980s, the concept of psychological well-being has started to be used within experimental studies and is known as the realization of one's self against difficult circumstances and of one's potential for a meaningful life (Ryff et al., 1999). In other words, psychological well-being means the management of existential challenges encountered in life, such as personal development, meaningful life pursuit, and good interpersonal skills (Keyes et al., 2002).

Having reviewed the literature, there are only a few studies examining the relationship between humor and psychological well-being (Celso et al., 2003; Kuiper \& McHale, 2009). It is anticipated that humor has a positive impact on psychological wellbeing, given that humor positively affects the individual and their environment (Özbay et al., 2012; Satıc1 \& Deniz, 2017), that it contributes to cope with challenges (Celso et al., 2003), and that it enhances interpersonal relations (Houston et al., 1998). In fact, 
humor is related to psychological well-being as it not only preserves welfare but also contributes to coping with challenges (Maiolino \& Kuiper, 2016). Furthermore, humor is considered a unique method of interaction, which is used to keep communication active in everyday life, mitigate interpersonal tension, and improve resilience (Martin, 2001). Therefore, the relationship between psychological counselors' coping humor and their psychological well-being was considered worthy of investigation in this research study.

Another concept that positively affects psychological well-being alongside coping humor is psychological resilience. Psychological resilience refers to the power of resistance against challenging circumstances in life (Basım \& Çetin, 2011; Terzi, 2005). With positive psychology, some individuals are psychologically regarded resilient as they preserve their mental balance through activating their positive traits as opposed to negative experiences (Rutter, 1999). Studies have begun to research individuals who have managed to overcome negative circumstances and transform into healthy individuals with self-respect, although they had been exposed to extremely stressful conditions during their upbringing (Stewart et al., 1997). The concept of resilience, etymologically coming from the Latin word of "resiliens", is used to describe this type of individual, referring to having qualities such as "pulling one's self together", flexibility, and being quick to 'bounce back' (Hoşoğlu et al., 2018). In the relevant literature, psychological resilience refers to the ability to resist against life-threatening factors, uncertainties, and poor life conditions (A ğırkan \& Kağan, 2017), quick 'bouncing back' and robust 'coping with' (Luthans et al., 2006).

While individuals try to adapt themselves to the changing circumstances in the surrounding environment, they may be negatively affected by specific issues that cannot be tackled and their mental health may suffer. For instance, bereavement of a loved one, job loss, deteriorating economic conditions, epidemics and detriments of natural disasters may hamper individuals' coping strength. Particularly, individuals with insufficient coping strength may feel vulnerable and that vulnerability may increase stress and anxiety, reduce their psychological well-being, and cause certain adaptation problems and physical disorders (Moran \& Hughes, 2006). However, some individuals continue to persevere and are observed to draw on their strength and stamina to 'bounce back', so to speak, from the detriments of extreme disaster (Ağırkan \& Kağan, 2017). It is seen that these individuals bear certain traits, which are also known as life skills, such as interpersonal communication, problem-solving, decision-making, physical fitness, identity development, and sense-making of life (Terzi, 2005). Those individuals can be said to display resilience against challenges in life by practicing life skills and aim to build a meaningful life based on their objectives, and concurrently, to live a healthy life in all personal and social areas (Öz \& Bahadır Y1lmaz, 2009).

It is stated that individuals resort to humor to cope with challenges they encounter by imagining humorous situations and making jokes or displaying behavior that may be funny (Yerlikaya, 2009). It is known that coping humor, as an important mediator of resilience, contributes to the emergence of positive emotions, and subsequently, well-being (Açıkgöz, 2016). Studies have shown that humor and a sense of humor, improve physical and psychological health and contribute to the enhancement of an individual's welfare (İlhan, 2005). In fact, humor enables individuals to reevaluate threatening and stressful life experiences with a positive outlook and helps 
them to put challenges into perspective (Satic1 \& Deniz, 2017). There are also a variety of findings in the relevant literature which conclude that coping humor increases resilience (Akgün \& Uz Baş, 2020; Richardson, 2002). In light of such evidence, it is considered that psychological resilience may explain the relationship between coping humor and psychological well-being.

Schools' psychological counselors have an important role in mental health, service for pupil personality, and managerial duties (Şimşek \& Tanaydın, 2002). In as much as they are responsible for pupils' well-being, they are responsible for teachers' and parents' mental issues, if any, and their impact on pupils and children. There are few studies suggesting that psychological counselors' job satisfaction and performance are negatively affected by both challenging work conditions at schools and busy and stressful work life (Balay, 2000). Henceforth, psychological counselors may feel under stress due to the working environment (Arslan, 2018; Çoban, 2005). Their well-being is of primary importance both for them and for the quality of their work.

Extended exposure to stress increases inner tension and psychical disorders and thus, reduces the productivity of individuals (Balaban, 2000). If stress is not dealt with accordingly, it results in the decline of productivity, dissatisfaction and causes damage to intimate relationships (Baltaş \& Baltaş, 2000). Some studies have demonstrated that psychological resilience is effective in coping with stressful life events (Kosaka, 1996; Terzi, 2005), reducing the detrimental effects of stress, and preventing inner tension from causing illness (Kobasa, 1979). It is of particular importance that psychological counselors are equipped to develop appropriate strategies in order to find ways in which their well-being and resilience can be improved and stress can be coped with, given that they are more likely to experience burnout (Kesler, 1991) and become exposed to stress at a higher level (Arslan, 2018; Çoban, 2005).

In recent years, there has been an increasing tendency in the discipline to focus on such positive domains as well-being, humor, optimism, welfare, resilience, flexibility, and compassion instead of such negative ones as depression, anxiety, and fear (Karaırmak \& Siviş Çetinkaya, 2011; Kuiper, 2012; Pidgeon \& Keye, 2014). In the literature, there has been further interest in researching the positive domains and their relationships since the 2000s (Pidgeon \& Keye, 2014; Souri \& Hasanirad, 2011). Therefore, it can be argued that studies, which aim to identify and improve such personal traits that individuals can perform as strengths and feel better, have gained particular importance. However, when the literature is examined, there are few studies examining the relationships between psychological well-being, humor, and psychological resilience. Similarly, only a few studies are investigating such concepts as well-being, resilience and humor with a particular focus on psychological counselors working at schools (Arslan, 2018; Bulut \& Erdoğan Akça, 2019). Therefore, this research aims to fill this identified gap in the literature with its findings and make an original contribution to psychological counseling.

\section{Present Study}

This research aims to examine the relationship between psychological counselors' use of coping humor, psychological well-being, and psychological resilience and explore the mediating role of psychological resilience in the relationship 
between humor as a coping mechanism and psychological well-being. The conceptual model that is used in this research is shown in Figure 1.

Figure 1

Conceptual Model of the Research

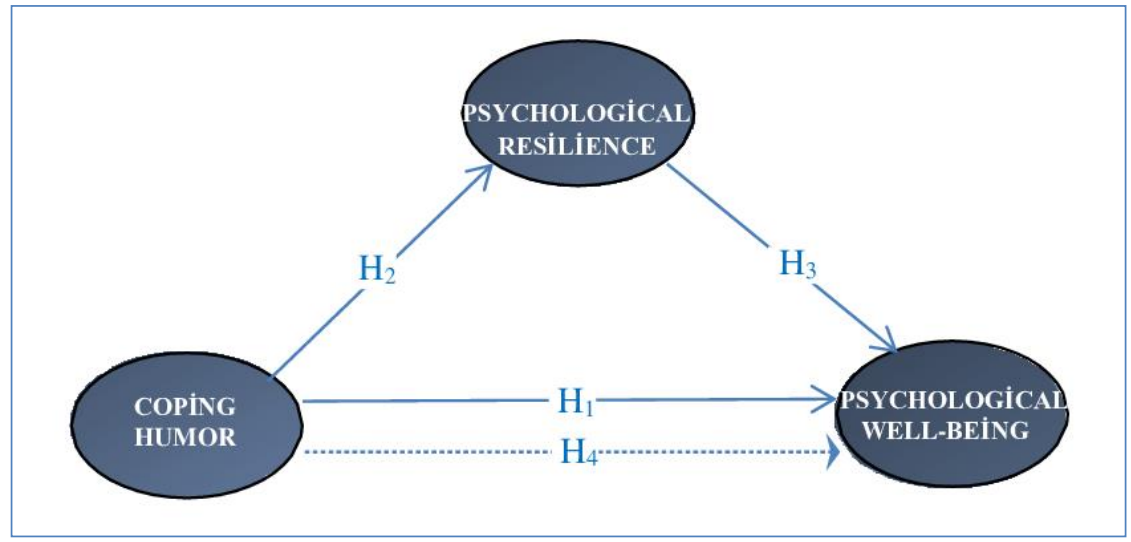

The below hypotheses are tested with the conceptual model presented in Figure 1.

$\mathrm{H}_{1}$ : There is a positively significant relationship between coping humor and psychological well-being.

$\mathrm{H}_{2}$ : There is a positively significant relationship between coping humor and psychological resilience.

$\mathrm{H}_{3}$ : There is a positively significant relationship between psychological resilience and psychological well-being.

$\mathrm{H}_{4}$ : The psychological resilience has a mediating role between coping humor and psychological well-being.

\section{Method}

\section{The Research Model}

This research is designed as quantitative research and uses the correlation research model (Karasar, 2005). The structural equation model (SEM) is used in the research to investigate the mediating role of psychological resilience in the relationship between psychological counselors' use of humor as a coping mechanism and their psychological well-being. The structural equation model is a statistical model used to identify directly-measurable and not-directly-measurable variables in causation and relationally (Wothke, 2010). It aims to explore whether the pre-determined relational patterns can be supported or not.

\section{Research Participants}

Research participants consisted of 228 psychological counselors who work in different schools and institutions across Turkey, affiliated with the Turkish Ministry of National Education. The research uses the convenience sampling method. While this method of sampling not only economizes on human resources, it is also a preferred method due to its cost-effectiveness and time-saving features (Büyüköztürk, 2019). 
Although using the whole population as the universe of the research would be ideal, such an approach would not generally be preferred as it would be significantly timeconsuming and costly. Thus, convenience sampling is preferred in this study (Leiner, 2014). In the convenience sampling method, the main assumption is that the sample is homogeneously distributed. It is assumed that the randomly selected sample is not different from the universe (Saunders et al., 2012). In the research, survey battery tests are prepared via "Google Form", sent to participants as digital texts, and then participants respond to these scales and return the relevant evidence to the researcher as digital texts. The scale forms are shared with psychological counselors through WhatsApp groups by Provincial and District Directorates of Turkish National Education. Information about the aim and the ethics of the research, based on the principles of consent and confidentiality of research participants, was provided in the messages sent via these groups.

The demographics of participants is composed of 57\% ( $n=130)$ female, $43 \%$ $(n=98)$ male, and $84.6 \%(n=193)$ people with undergraduate degrees and $15.4 \%(n=35)$ with postgraduate degrees. Considering professional seniority, the years of seniority lie at the 1-25 year-band and the mean of years of seniority is 5.9 with the standard deviation value of 4.42. The age band of participants is $23-50$ and the average age is 29.7 with a standard deviation value of 4.96 . Moreover, $3.9 \%(n=9)$ of participants work in pre-school education, $20.6 \%(n=47)$ in primary, $35 \%(n=80)$ in lower secondary, $30.3 \%(n=69)$ in upper secondary, and 8.8\% $(n=20)$ in counselling and research centers $(\mathrm{CRC})$ and $1.3 \%(n=3)$ in other educational institutions such as (community colleges, vocational schools, and science and arts centers). Additionally, 76.3\% ( $n=174)$ of participants work in city centers whilst $23.7 \%(n=54)$ in towns and villages.

\section{Instruments}

Coping Humor Scale (CHS): Yerlikaya (2003) has translated Martin and Lefcourt's (1983) CHS into Turkish. It is a self-report scale consisting of 7 items and a 4-point Likert scale (1=I strongly disagree, 4=I strongly agree). Scores in the onedimensional scale are expected to be between 7 and 28. If one gets a high score on the scale, it means that they have a high level of coping humor. The coefficient of internal consistency of scale reliability test is .67 (Yerlikaya, 2009). Following the confirmatory factor analysis (CFA) conducted in the scope of this study to identify the construct validity of the CHS, this research has found that the scale is unifactorial and model fit values indicate a good fit (RMSEA=.07, GFI=.95, AGFI=.89, CFI=.93, SRMR=.07). In addition, the reliability test of the total scale for this study shows that Cronbach's Alpha coefficient is .79 and total item-correlations are between .36 and .62 .

Psychological Well-being Scale (PWS): Telef (2013) has translated Diener et al. (2009) PWS into Turkish. It consists of 8 items and 7-pointLikert scale (1=I strongly disagree, 7=I strongly agree). The scale was initially entitled "Psychological WellBeing Scale" and then re-named "Psychological Flourishing Scale". As there is not a clear correspondence for the word "flourishing" in the Turkish language, Telef (2013) has called it "Psychological Well-Being". All of the items in the scale are positively reported and scores in the scale are expected to be between 8 and 56. If one gets a high score on the scale, it means that they simultaneously have multiple psychological strengths and resources. Validity tests of the scale show that the scale is unifactorial and 
explains $42 \%$ of the total variance. Factor loadings of scale items are between .54 and .76. Reliability tests of the scale show that the coefficient of internal consistency is .80 (Telef, 2013). Even though the scale does not provide individual measures for psychological well-being, it gives an overview regarding the positive functions within important areas (Diener et al., 2010). Following the CFA to identify the construct validity of the PWS, this research has found that the scale is unifactorial and model fit values indicate a good fit(RMSEA=.08, GFI=.95, AGFI=.90, CFI=.93, SRMR=.06). In addition, the reliability test of the total scale for this study shows that Cronbach's Alpha coefficient is. 81 and total item-correlations are between .38 and .61 .

Resilience Scale for Adults (RSA): Basım and Çetin (2011) have translated Friborg et al. (2005) RSA into Turkish. The scale consists of 33 items and a 5-point Likert scale. The scale provides research participants with positive and negative items on different sides in order for them to not be biased. There are boxes with five choices, which are put in between statements presented on each side. There are sixsubdimensions in the RSA such as "perception of self, planned future, structured style, social competence, family cohesion, and social resources". Reliability tests of the scale show that Cronbach's Alpha coefficient of sub-dimensions is between .66 and .81 . Factor loadings of scale items are between .41 and .70 and the explained total variance is measured as \%54 (Basım \& Çetin, 2011). Following the CFA of RSA, this research has found that the 6-dimensional construct of the scale is supported and model fit values indicate good fit (RMSEA=.07, GFI=.97, AGFI=.93, CFI=.97, SRMR=.03). In addition, the reliability test of the total scale for this study shows that the Cronbach's Alpha coefficient is .82 and total item-correlations are between .34 and .63 .

Personal Information Sheet: It comprises personal information of research participants on the basis of gender, age, educational status, year of professional seniority, the year-level of education in schools that they work, and place of residence.

\section{Data Collection Process}

Prior to the data collection with the aforementioned scales, the ethical approval for this research is granted by Van Yüzüncü Yıl University's Ethics Committee for Social Sciences and Humanities. The approval is granted with the decision dated 30/12/2020 and numbered with 2020/15-54. The research has collected data from 228 of 233 psychological counselors upon their consent.

\section{Data Analysis}

The data is analyzed via SPSS 23 and AMOS 24 package program. Prior to the analysis, the data entered in the SPSS is checked in terms of deficiency and error. Then, the findings were checked for normality. Before the analyses were made, whether there were outliers in the data were checked using histograms and boxplots in the SPSS program. In addition, in the checks made with the Mahalanobis distance test, it was seen that 5 data were outliers and these data were removed from the data set. In the data analysis, first, the frequency values of the data set are checked. Then, values for skewness and kurtosis of all scales and their sub-dimensions are examined. Lastly, the minimum and maximum values of descriptive statistics, mean, and standard deviation are evaluated. Reliability values of all scales used in this research and inter-variable relationships to develop a model following the checks of linearity and co-variance 
values are measured with Pearson Product-moment correlation coefficient.Also, it was checked whether there is a multi-collinearity problem in the data. After confirming measurement models of measurement tools with confirmatory factor analysis, the hypothetical model is also tested with a measurement model and has found that measurement values are acceptable. The model suggested at the end of this section is analyzed with structural equation modeling (SEM) and findings are discussed below.

The most important criteria in the evaluation of structural equation model studies are model fit values. Therefore, model fit values should be examined first in the measurement model. In order to evaluate the validity of the model, the model fit value specified by Karagöz (2016) and Meydan and Şeşen (2015) were taken as a reference. These values are given in Table 1.

Table 1

Model Fit Values

\begin{tabular}{ccc}
\hline Model Fit Value & Good Fit & Acceptable Fit \\
\hline$\chi^{2}$ & $.05<p \leq 1$ & $.01<p \leq .05$ \\
$\chi^{2} / d f$ & $\chi^{2} / d f \leq 3$ & $\chi^{2} / d f \leq 5$ \\
RMSEA & RMSEA $\leq .05$ & RMSEA $\leq .08$ \\
SRMR & $0<$ SRMR $\leq .05$ & $0<$ SRMR $\leq .08$ \\
GFI & $.90 \leq$ GFI & $.85 \leq \mathrm{GFI}$ \\
AGFI & $.90 \leq \mathrm{AGFI}$ & $.89 \leq \mathrm{AGFI} \leq .85$ \\
CFI & $.90 \leq \mathrm{CFI}$ & $.85 \leq \mathrm{CFI}$ \\
IFI & $.95 \leq \mathrm{IFI}$ & $.94 \leq \mathrm{IFI} \leq .90$ \\
\hline
\end{tabular}

Karagöz, 2016; Meydan \& Şeşen, 2015.

\section{Results}

Before testing the structural equation modeling, uni-variate normal distribution is assumed in the multivariate data analysis as one of the assumptions of the modeling (Kline, 2015; Şimşek, 2007). Table 2 below presents the descriptive statistics of the research scale and its sub-dimensions as well as values for skewness and kurtosis.

Table 2

Descriptive Statistics of the Research Scale and Its Sub-Dimensions, and Values for Skewness and Kurtosis

\begin{tabular}{|c|c|c|c|c|c|c|c|c|}
\hline Variables & $\begin{array}{l}\text { Number } \\
\text { of Items }\end{array}$ & $N$ & Max. & Min. & $\bar{X}$ & $S S$ & Skewness & Kurtosis \\
\hline Psycho. Well-being & 8 & 228 & 55 & 33 & 46.04 & 4.42 & -.73 & .37 \\
\hline Coping Humor & 7 & 22 & 28 & 13 & 20.14 & 2.98 & -.09 & -.27 \\
\hline Psycho. Resilience & 33 & 228 & 158 & 94 & 129.5 & 13.86 & -.35 & -.46 \\
\hline Perception of Self & 6 & 228 & 30 & 15 & 23.39 & 3.32 & -.22 & -.46 \\
\hline
\end{tabular}




\begin{tabular}{lllllllll} 
Planned Future & 4 & 228 & 20 & 8 & 15.78 & 2.76 & -.58 & .06 \\
Structured Style & 4 & 228 & 20 & 6 & 15.19 & 2.73 & -.33 & -.12 \\
Social Competence & 6 & 228 & 30 & 13 & 23.43 & 3.36 & -.41 & .14 \\
Family Cohesion & 6 & 228 & 30 & 10 & 22.47 & 4.29 & -.59 & .02 \\
Social Resources & 7 & 228 & 35 & 17 & 29.03 & 3.43 & -.59 & .39 \\
\hline
\end{tabular}

Two important factors of normality are skewness and kurtosis. It is expected to have a coefficient of skewness between -1 and +1 , and the value of kurtosis close to null (Büyüköztürk, 2019). Similarly, Tabachnick and Fidell (2015) state that the data is in normal distribution if values for skewness and kurtosis are between +3 and -3 . Similarly, Table 2 demonstrates that all scales and the values of skewness and kurtosis for sub-dimensions of those scales are between -1 and +1 , and hence, the data is in normal distribution (Büyüköztürk, 2019).

Table 2 demonstrates that the mean of participants' scores for psychological well-being is $46.04 \pm 4.42$, for coping humor $20.14 \pm 2.98$, and for psychological resilience $129.05 \pm 13.86$. In order to identify participants' levels of psychological wellbeing, coping humor, and psychological resilience, the comparison of each scale to their median values are made with one sample $t$-test analysis. Findings show that there is a highly significant difference between the counselors' scores for psychological wellbeing $\left(\mathrm{t}_{(226)}=47.88\right.$; sd: $\left.227 ; p<.05\right)$, for coping humor $\left(\mathrm{t}_{(226)}=13.38\right.$; sd: $\left.227 ; p<.05\right)$, and for psychological resilience $\left(\mathrm{t}_{(226)}=33.25 ; \mathrm{sd}: 227 ; p<.05\right)$ and the mean values of scales.

In order to use structural equation modeling, there must be significant relationships between dependent, independent and mediator variables (Baron \& Kenny, 1986; Kline, 2015). For this reason, the Pearson Product-moment correlation coefficient was used to determine the relationships between the variables. Table 3 presents the correlation between participants' psychological well-being, coping humor, and psychological resilience.

Table 3

Correlational Relationship between Variables Used in the Conceptual Model

\begin{tabular}{|c|c|c|c|c|c|c|c|c|c|}
\hline & PWB & $\mathrm{CH}$ & PR & PS & $\mathrm{PF}$ & SS & $\mathrm{SC}$ & FC & SR \\
\hline PWB & 1 & & & & & & & & \\
\hline $\mathrm{CH}$ & $.36^{* *}$ & 1 & & & & & & & \\
\hline PR & $.65^{* *}$ & $.40^{* *}$ & 1 & & & & & & \\
\hline PS & $.56^{* *}$ & $.44^{* * *}$ & $.73 * *$ & 1 & & & & & \\
\hline $\mathrm{PF}$ & $.62 * *$ & $.32^{* *}$ & $.74 * *$ & $.60^{* *}$ & 1 & & & & \\
\hline SS & $.37 * *$ & $.08^{* *}$ & $.57 * *$ & $.33 * *$ & $.41 * *$ & 1 & & & \\
\hline $\mathrm{SC}$ & $.41 * *$ & $.42 * *$ & $.67 * *$ & $.39 * *$ & $.34 * *$ & $.28 * *$ & 1 & & \\
\hline $\mathrm{FC}$ & $.38 * *$ & $.18^{* *}$ & $.72 * *$ & $.36^{* *}$ & $.48^{* *}$ & $.22 * *$ & $.39 * *$ & 1 & \\
\hline SR & $.46^{* *}$ & $.21^{* *}$ & $.78^{* *}$ & $.49 * *$ & $.49^{* *}$ & $.39 * *$ & $.45^{* *}$ & $.55^{* *}$ & 1 \\
\hline
\end{tabular}

N: 228; **p<.01; PWB: Psychological Well-being; CH: Coping Humor; PR: Psychological Resilience; PS: Perception of Self; PF: Perception of Future; SS: Structured Style; SC: Social Competence; FC: Family Cohesion; SR: Social Resources 
If variables in the data set have a highly significant correlation, it hints at a multi-collinearity problem. Field (2009) suggests removing variables causing high-level correlation from the model. In order to identify whether or not there is multi-collinearity between variables, the Pearson Product-moment correlation coefficients are checked. Since the correlation values don't exceed the critical value of .90 , it can be concluded that there isn't multi-collinearity problem in the data (Kline, 2015).

Having examined the correlation results in the findings in the Table 3 suggests that all variables have a positively significant correlation with each other. Therefore, it is evident that there is a positively significant relationship between psychological counselors' level of psychological well-being, and of coping humor $(r=.36, p<.01)$ and psychological resilience $(r=.65 ; p<.01)$. In addition, there is a positively significant correlation between participants' level of psychological resilience and coping humor ( $r=.40, p<.01$ ). Thus, it is evident that the study supports the $\mathrm{H}_{1}, \mathrm{H}_{2}$ and $\mathrm{H}_{3}$ hypotheses of the research.

\section{Model Tests}

\section{Model 1. Relationship between Coping Humor and Psychological Well-being}

The first model of the research investigates the relationship between psychological counselors' level of coping humor and psychological well-being. Baron and Kenny (1986) suggest that there can be a relationship of mediation if there is a meaningful relationship between independent (coping humor) and dependent (psychological well-being) variables. Henceforth, this study investigates the predictive power of psychological counselors' level of coping humor over their psychological well-being.

Figure 2 presents the predictive power of psychological counselors' level of coping humor over their psychological well-being, analyzed through structural equation modeling.

Figure 2

Predictive Power of Coping Humor over Psychological Well-being

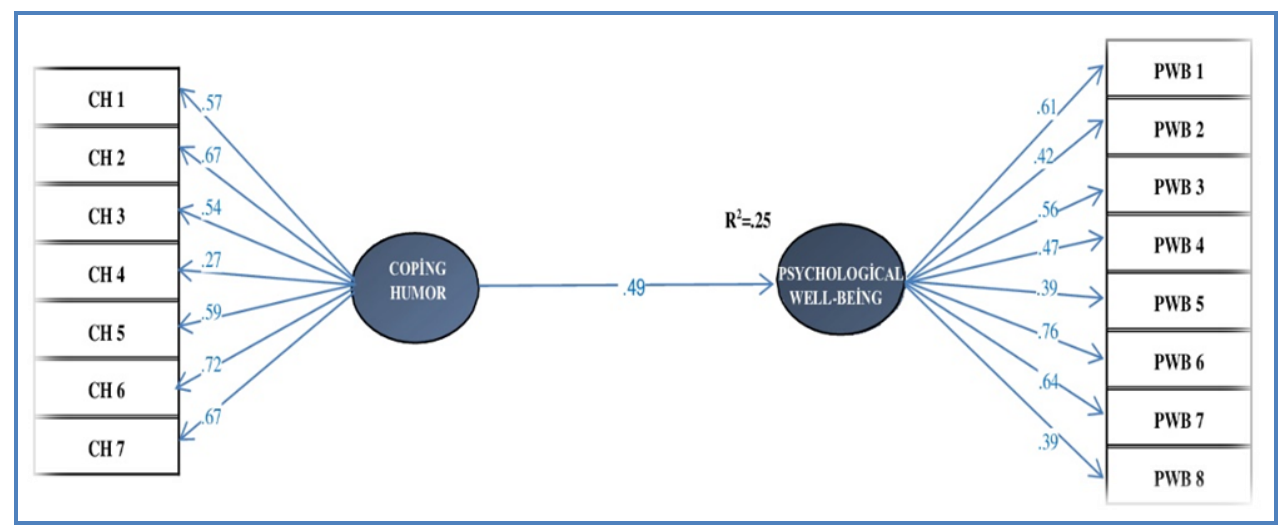

When the $\mathrm{R}^{2}$ value given in Figure 2 is reviewed, it can be seen that $25 \%$ of the change in psychological well-being can be explained by coping humor. A review of the $\beta$ value given in Figure 2 finds that coping humor has a significant predictor moderate level of predictive power over psychological well-being (Cohen, 2003).Thus, it is found 
that the predictive power of coping humor over psychological well-being is at the level of .49.Table 4 demonstrates the model fit values presented in Figure 2.

Table 4

Model Fit Values presented in Figure 2

\begin{tabular}{cccc}
\hline Good Fitting & Acceptable Fitting & Fit Value & Fitting \\
\hline$\chi^{2} / d f \leq 3$ & $\chi^{2} / d f \leq 5$ & 2.21 & Good fitting \\
RMSEA $\leq .05$ & RMSEA $\leq .08$ & .07 & Acceptable fitting \\
$0<$ SRMR $\leq .05$ & $0<$ SRMR $\leq .08$ & .06 & Acceptable fitting \\
$.90 \leq \mathrm{GFI}$ & $.85 \leq \mathrm{GFI}$ & .90 & Good fitting \\
$.90 \leq \mathrm{AGFI}$ & $.89 \leq \mathrm{AGFI} \leq .85$ & .93 & Good fitting \\
$.90 \leq \mathrm{CFI}$ & $.85 \leq \mathrm{CFI}$ & .97 & Good fitting \\
$.95 \leq \mathrm{IFI}$ & $.94 \leq \mathrm{IFI} \leq 90$ & .93 & Acceptable fitting
\end{tabular}

In Table 4, it can be seen that the model is significant with values of $\chi^{2}(190)$ and $\chi^{2} / d f$ (2.21). Having examined the model fit values, it can be seen that the GFI=.90, AGFI=.90 and CFI=.90 values are of good fit (Kline, 2015; Tabachnick \& Fidell, 2015) and the RMSEA=.07, SRMR=.06 and IFI=.93 values are within acceptable boundaries of fit (Karagöz, 2016; Meydan \& Şeşen, 2015).

\section{Model 2. The Mediating Role of Psychological Resilience in the Relationship} between Coping Humor and Psychological Well-being

Figure 3 presents the model developed for the examination of the mediating role of psychological resilience in the relationship between coping humor and psychological well-being within the use of structural equation modeling.

Figure 3

The Mediating Role of Psychological Resilience in the Relationship between Coping Humor and Psychological Well-being

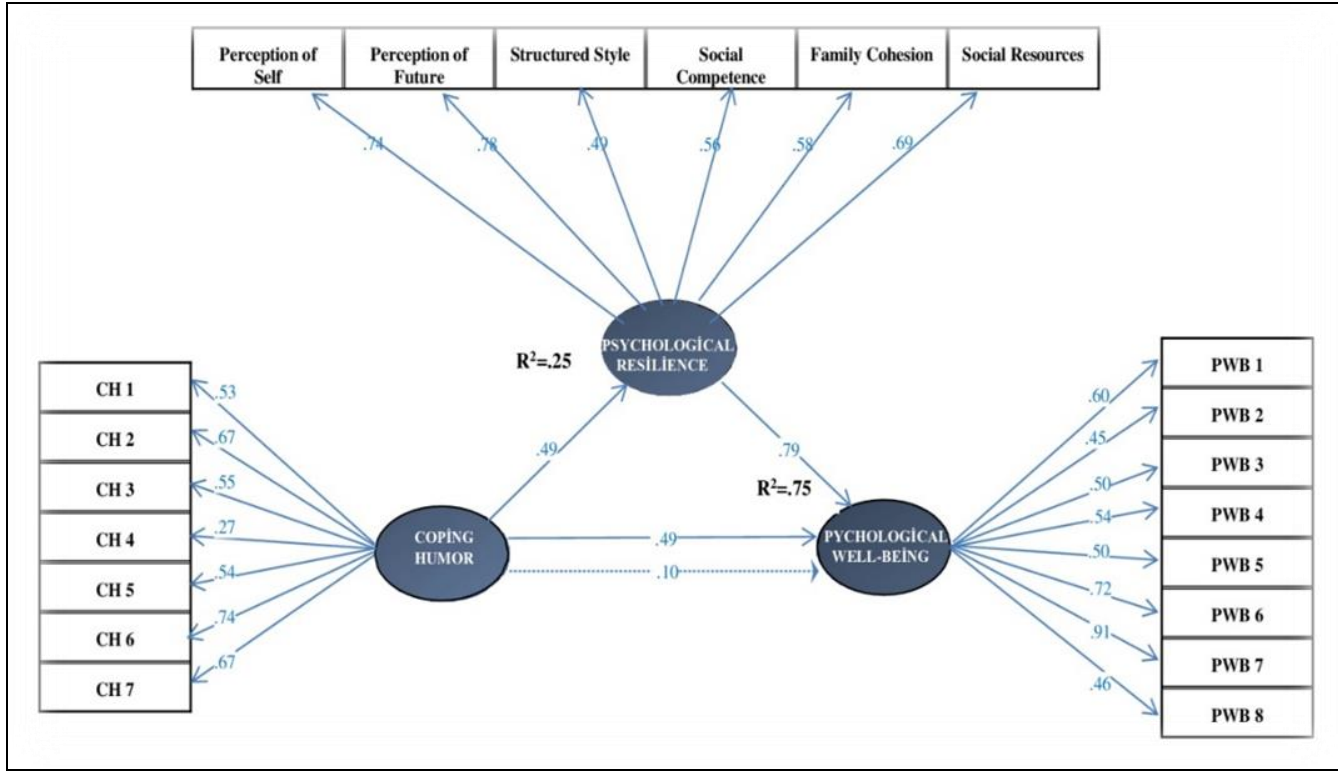


When the $\mathrm{R}^{2}$ values given in Figure 3 are examined, it can be stated that $25 \%$ of the total change in resilience can be explained by coping humor and $71 \%$ of the total change in psychological well-being is explained by resilience and coping humor. A review of the $\beta$ value given in Figure 3 shows that psychological resilience with coping humor $(\beta=.49, p=.01)$ is moderate and psychological resilience has high predictive power on psychological well-being ( $\beta=.79, p=.01$ ) (Cohen, 2003).

As Figure 3 shows, the predictive power of coping humor over psychological well-being drops from the level of .49 to the level of .10 as found in the structural equation modeling that has tested the mediating role of psychological resilience in the relationship between coping humor and psychological well-being. Table 5 below present's model fit values presented in Figure 3.

Table 5

Model Fit Values presented in Figure 3

\begin{tabular}{cccc}
\hline Good Fitting & Acceptable Fitting & Fit Value & Fitting \\
\hline$\chi^{2} / d f \leq 3$ & $\chi^{2} / d f \leq 5$ & 2.21 & Good fitting \\
RMSEA $\leq .05$ & RMSEA $\leq .08$ & .07 & Acceptable fitting \\
$0<$ SRMR $\leq .05$ & $0<$ SRMR $\leq .08$ & .07 & Acceptable fitting \\
$.90 \leq \mathrm{GFI}$ & $.85 \leq \mathrm{GFI}$ & .85 & Acceptable fitting \\
$.90 \leq \mathrm{AGFI}$ & $.89 \leq \mathrm{AGFI} \leq .85$ & .91 & Good fitting \\
$.90 \leq \mathrm{CFI}$ & $.85 \leq \mathrm{CFI}$ & .96 & Good fitting \\
$.95 \leq \mathrm{IFI}$ & $.94 \leq \mathrm{IFI} \leq 90$ & .95 & Good fitting \\
\hline
\end{tabular}

Having examined the model fit values presented in Figure 3 shown in Table 5, it is found that the model is significant with values of $\chi^{2}(405)$ and $\chi^{2} / d f(2.21)$. A review of model fit indices shows that the AGFI=.91, CFI=.96 and $\mathrm{IFI}=.95$ values provide a good fit (Kline, 2015) and the RMSEA=.07, SRMR=.07 and GFI=.85 values are within acceptable boundaries of fit (Karagöz, 2016; Meydan \& Şeşen, 2015).

The results of the bootstrapping analysis performed with a 5.000-resampling method on whether the indirect effects of partial mediation found in the model are significant or not are given in Table 6 .

Table 6

Bootstrapping Results for the Mediating Role of Psychological Resilience in the Relationship between Coping Humor and Psychological Well-Being

\begin{tabular}{ccccccc}
\hline & Bootstrap & & \multicolumn{2}{c}{$95 \%$ Confidence Interval } & & \\
Indirect Effects & Coefficient & $\mathrm{SE}$ & Lower Limit & Upper Limit & $R^{2}$ & $F$ \\
\hline $\mathrm{CH} \rightarrow \mathrm{PR} \rightarrow \mathrm{PWB}$ & .463 & .092 & .304 & .663 & .75 & $70.09 * *$ \\
\hline
\end{tabular}

$* * p<.01, * p<.05$, SE: Standard Errors, CH: Coping Humor, PR: Psychological Resilience, PWB: Psychological Well-Being 
An examination of Table 6 shows a significant indirect relationship between psychological resilience and psychological well-being by means of coping humor (Bootstrap coefficient=.463, 95\% confidence interval=.304 and .663). Bootstrapping results were found to be statistically significant as they did not include zero values for lower and upper limits in the $95 \%$ confidence interval. These results demonstrate that psychological resilience partially has a mediating role in the relationship between coping humor and psychological well-being.

\section{Discussion and Conclusion}

This study has investigated the mediating role of psychological resilience in the relationship between coping humor and psychological well-being. Findings show that there is a positively significant correlation in the relationships between coping humor, psychological resilience, and psychological well-being, and suggest that coping humor is an important descriptive variable for psychological resilience and psychological wellbeing. Moreover, the study finds that psychological resilience explains psychological well-being, and partially has a mediating role between coping humor and psychological well-being. Likewise, it is found that coping humor explains psychological well-being both directly and through psychological resilience. Research findings demonstrate that the conceptual model developed to holistically describe psychological well-being is supported and indicates good-fit values. This section discusses the research findings regarding the developed model and the tested hypotheses within the theoretical framework and makes suggestions.

This research concludes that the means of psychological counselors' scores for coping humor, psychological resilience, and psychological well-being are above the mean values. It can be argued that this result is related to psychological counselors' educational backgrounds and vocational fields. Psychological counselors' educational background enables them to cope with their psychological problems (Aladağ, 2014); hence their education may contribute to their well-being. As previously shown (Akça Erdoğan, 2018), psychological counselors have high levels of psychological well-being. As psychological counselors work in mental health and help individuals with a variety of personality traits and mental health issues (Gülbahçe \& Özkurt, 2016), it is anticipated that they have a high level of psychological well-being and resilience. This requires them to continuously improve themselves professionally and update their areaspecific knowledge (Karairmak \& Siviş, 2008). Thus, it can be noted that psychological counselors have a high level of psychological well-being and psychological resilience because it is a requirement of their job. Following the overall analysis of research findings, it can be inferred that psychological counselors quickly re-build themselves against obstacles and challenges, cope with difficult situations and experiences through having a sense of humor, and are more likely to view stressful and difficult experiences with a positive outlook.

Research findings show a positive correlation between coping humor and psychological well-being. Therefore, $\mathrm{H}_{1}$ the first hypothesis of the research, was confirmed. Previous research findings support that coping humor directly and significantly relationship psychological well-being (Açıkgöz, 2016; Akça Erdoğan, 2018; Alvord et al., 2011; Kuiper \& Martin, 2010; Kuiper \& McHale, 2009; Satıc1 \& Deniz, 2017). Considering that psychological well-being increases individuals' potential 
to pursue a meaningful life (Telef, 2013) and that humor positively contributes to individuals' lives at large (Martin, 2001), it is anticipated that there is a significant correlation between humor and psychological well-being. Similarly, there is a close relationship between psychological well-being and self-realization (Ryan \& Deci, 2001). In general, psychological well-being is related to one's life goals, interpersonal skills, personal responsibilities in life (Ryff \& Keyes, 1995) and positive moods (Kuyumcu, 2013) and hence, it also has significant relationships with the sense of humor.

Research findings demonstrate that there is a positively significant correlation between coping humor and psychological resilience. Therefore, this result confirms the second hypothesis of the research $\mathrm{H}_{2}$. This particular relationship is consistent with many other studies in the existing literature (Açıkgöz, 2016; Akgün \& Uz Baş, 2020; Olsson et al., 2003; Satıcı \& Deniz, 2017). Individuals who use humor as a coping mechanism are able to detect and comprehend humor in their life events (Ruch, 1998). Therefore, it can be said that psychological counselors have the ability to re-evaluate situations and look at them from a positive perspective by using humor as a coping mechanism. In the existing literature, some studies support the findings of this research. For instance, it is evident that humor preserves individuals' mental health as used as a balancing factor against challenges and obstacles in life (Thorson et al., 1997). It is also found that the therapeutical use of humor supports individuals' physical, emotional, cognitive, and social development and hence, increases their psychological resilience (Çakmak, 2012).

Another finding of this research demonstrates that there is a significant correlation between psychological resilience and psychological well-being, which is the third hypothesis of the study. Studies in the existing literature support this finding (Fredrickson, 2001; Karacaoğlu \& Köktaş, 2016; Malkoç \& Yalçın, 2015; Pidgeon \& Keye, 2014; Ryff \& Singer, 2003). Psychologically resilient individuals successfully cope with the negative changes in their lives, and their successful coping also contributes to their well-being (Wagnild, 2009). Ryff et al. (1998) suggest that psychological resilience builds upon psychological well-being against challenges and also enhances it.

Research findings showed that there is a significant relationship between coping humor and psychological well-being through the mediator of psychological resilience. This finding confirms the fourth hypothesis of the research, $\mathrm{H}_{4}$. There are no studies in the existing literature, which concurrently focus on the relationships of these three variables. Nevertheless, it is found that previous studies support this network of relations. Based on this finding, it can be suggested that coping humor enhances psychological well-being through psychological resilience. It is found that, with the use of humor, individuals look at life events from a different perspective by unraveling humorous, funny, and witty aspects of those events (Chauvet \& Hofmeyer, 2007) and subsequently, by identifying poor aspects of the events (Lefcourt, 2001), which then facilitates coping process. Thus, it can be argued that humor increases individuals' psychological resilience and encourages them to focus on positive sides of events, or put differently, to be more optimistic. Moreover, these individuals may feel more satisfied with their lives, and more inclined to get social support and to establish more meaningful relationships (Ryff et al., 1999). Therefore, their psychological well-being 
can improve. Similarly, studies show that coping humor helps individuals be more flexible (Kolburan et al., 2019) and be more resilient (Thorson et al., 1997), thus it successfully contributes to the maintenance of their mental health. Furthermore, because coping humor operates as a balancing factor amidst challenges (Akgün \& Uz Baş, 2020), it can improve psychological resilience and hence, enhance psychological wellbeing.

\section{Limitations}

Of the limitations of the study, the first is the limitation related to the sampling method. As a result of convenience sampling, most of the selected participants in the sample were from the eastern provinces of Turkey and were new to the profession (mean working time $=5.9 \pm 4.42$ ); thus, constituting a significant limitation in terms of the generalizability of the study.

Another limitation of the study is that only humor and psychological resilience were under taken in explaining psychological well-being. Therefore, since a variety of factors are effective in explaining psychological well-being, it may be suggested that different conceptual models can be used to explain psychological well-being in future studies.

The fact that the participants of the study were psychological counselors constitutes another limitation in terms of the applicability of the study to other segments of society. Again, since the data was collected by means of self-reporting measurement tools, some scores in the data obtained from the scales may be high due to the social desirability factor.

One other limitation of the study may be attributed to the validity and credibility of the data as being limited to the data collection tools which were used. The insufficient number of participants $(n=228)$ in this study is thought to be a significant limitation in terms of the generalizability of the research findings.

Finally, Covid-19 pandemic conditions in Turkey, and indeed globally, could be considered another limitation of the study. It may have been the case that the context of the scale items may have impacted the responses of those participating in the study.

\section{Suggestions}

In consideration of the importance and structure of the psychological counseling profession, it is suggested that the number of studies in the field of positive psychology for psychological counselors should increase. It is recommended that the importance should be placed on positive psychology concepts such as humor, resilience and psychological well-being. Information should be provided on the advantages of increasing the well-being of psychological counselors, not only in terms of their own well-being but also for the benefit of their clients. In addition, studies can be conducted on how psychological counselors can further use psychological well-being in their work settings. It may be recommended to provide in-service training or such activities as seminars on the importance of psychological well-being and giving expert advice on a variety of subjects.

As a result of the research, it was concluded that humor and psychological resilience are important factors in increasing the psychological well-being of psychological counselors. In light of these findings, psychological counselors can utilize 
various techniques, including humor and psychological resilience in the therapeutic process to improve their clients' psychological well-being.

In regard to further research on this topic, it may be suggested that a more comprehensive study can be conducted by adding variables related to how the work environment affects psychological counselors. Future studies may also be suggested to use both qualitative and quantitative data to explain psychological well-being. Studies that cover a wider age range of psychological counselors and a wider scope in terms of regional coverage may also be recommended. In order to eliminate the limitations of a cross-sectional study, the generalizability of the findings can be increased with longitudinal studies to be conducted in different time frames.

This study was conducted by using the correlational research model. Thus, it may be suggested to conduct experimental studies to explain psychological well-being in future studies. Experimental studies can also be carried out with psycho-educational groups that include various factors that may be considered to increase psychological resilience and coping humor.

Finally, since this study was conducted during the Covid-19 pandemic process, the same study can be repeated after the pandemic to minimize the effects of the pandemic.

\section{Statement of Responsibility}

Ferdi Yağan; determination of problem situation, determination of sample group, selection and application of data collection tools, methodology, literature review, analysis, writing-original draft and resources. Zöhre Kaya; planning and implementation of activities, methodology, validation, writing-original draft, arrangement, writingreview, reviewing and inspection, editing, visualization and supervision.

\section{Conflicts of Interest}

There are no conflicts of interest in this study.

\section{Author Bios:}

Zöhre Kaya is a lecturer at Van Yüzüncü Y1l University, Department of Educational Sciences, Division of Guidance and Psychological Counseling. She has national and international articles on Guidance and Psychological Counseling.

Ferdi Yağan, is a student $\mathrm{PhD}$ in Guidance and Psychological Counseling at Atatürk University.

\section{References}

Açıkgöz, M. (2016). Examining the relationship among the psychological resilience, humor styles and happiness level of medicine school students [Unpublished master's thesis]. Çağ University.

Ağırkan, M., \& Kağan, M. (2017). The relationship between value orientations and psychological resilience levels of university students. Journal of Erzincan University Faculty of Education, 19(3), 225-245. https://doi.org/10.17556/erziefd.335063 
Akça Erdoğan, B. (2018). The investigation of emotion management skills and psychological well-beings of school psychological counselors with regard to humor styles, which they use [Unpublished master's thesis]. Uludağ University.

Akgün, Ü., \& Uz Baş, A. (2020). Assertiveness and humor styles as predictors of resilience in high school students. PESA International Journal of Social Studies, 6(3), 217-231.

Aladağ, M. (2014). Critical incidents in individual counseling practicum supervision across different levels of counselor education. Journal of Education Ege, 15(2), 428-475. https://doi.org/10.12984/eed.82217

Allport, G. W. (1961). Pattern and growth in personality. Holt.

Alvord, M. K., Zucker, B., \& Grados, J. J. (2011). Resilience builder program for children and adolescent-enhancing social competence and self-regulation. Research Press.

Arslan, H. (2018). The relationship between happiness, resilience and addiction conditions of psychological consultants. Journal of Education in Health Sciences, 1(1), 17-35.

Balaban, J. (2000). Stress sources and coping techniques of teachers in elementary education. Journal of Education Pamukkale University Faculty, 7, 188-195.

Balay, R. (2000). Organizational commitment. Nobel Publishing.

Baltaş, A., \& Baltaş, Z. (2000). Stress and ways to cope. Remzi Press.

Baron, R. M., \& Kenny, D. A. (1986). The moderator-mediator variable distinction in social psychological research: Conceptual, strategic, and statistical considerations. Journal of Personality and Social Psychology, 51(6),

Basım, H. N., \& Çetin, F. (2011). Reliability and validity studies of resilience scale for adults. Journal of Turkish Psychiatry, 22(2), 104-114.

Boniwell, I. (2012). Positive psychology in a nutshell: The science of happiness. (3th ed.). Open University Press.

Bradburn, N. M. (1969). The structure of psychological well-being. Aldine.

Bulut, S., \& Erdoğan Akça, B. (2019). Examination of emotion management skills according to the humor styles used by school psychological counselors (guidance teachers). 3rd Eurasian Positive Psychology Congress, 13-14 April 2019.

Büyüköztürk, Ş. (2019). Data analysis handbook. Pegem Publishing.

Çakmak, A. (2012). Humor and therapeutic usage of humor. Presented at the II. International VI. National Psychiatric Nursing Congress. 4-7 October, Erzurum.

Celso, B. C., Ebener, D. J., \& Burkhead, H. (2003). Humor coping, health status, and life satisfaction among older adults residing in assisted living facilities. Aging and Mental Health, 7(6), 438-445. https://doi.org/10.1080/13607860310001594691

Chauvet, S., \& Hofmeyer, A. (2007). Humor as a facilitative style in problem-based learning environments for nursing students. Nurse Education Today, 27, 286-292. https://doi:10.1016/j.nedt.2006.05.008

Çiper Kaynar, A. (2019). Turkish adaptation of sense of humor questionnaire: Transliteral equivalence, reliability and validity study [Unpublished master's thesis]. Üsküdar University. 
Çoban, A. E. (2005). Peer supervision for school counselors. Mersin University Journal of the Faculty of Education, 1(1), 167-174. https://doi:10.17860/efd.52534

Cohen, J. (2003). A power primer. Psychological Bulletin, 112(1), 155-159. https://doi: 10.1037//0033-2909.112.1.155

Diener, E. (2009). Subjective well-being. The science of well-being. Social Indicators Research Series, USA, Springer,37, 11-58. https://doi.org/10.1007/978-90-4812350-6_2

Diener, E., Scollon, C. N., \& Lucas, R. E. (2009). The evolving concept of subjective well-being: The multifaceted nature of happiness. Advances in Cell Aging and Gerontology, 15, 187-219. https://doi.org/10.1007/978-90-481-2354-4_4

Diener, E., Wirtz, D., Tov, W., Kim-Prieto, C., Choi, D., Oishi, S., \& Biswas-Diener, R. (2010). New well-being measures: Short scales to assess flourishing and positive and negative feelings. Social Indicators Research, 97(2), 143-156. https://doi.org/10.1007/s11205-009-9493-y

Ergün Başak, B. (2012). The relationships between self-compassion, social connectedness, optimism and psychological resilience levels of low-income university students [Unpublished doctoral thesis]. Anadolu University.

Field, A. (2009). Discovering statistics using SPSS: Book plus code for E version of text (3th ed.). Sage Publication.

Frankl, V. E. (1984). Man's search for meaning. Washington Square Press.

Fredrickson, B. L. (2001). The role of positive emotions in positive psychology: The broaden-and-build theory of positive emotions. American Psychologist, 56(3), 218226. https://doi.org/10.1037/0003-066X.56.3.218

Freud, S. (1905). Jokes and their relation to the unconscious. Penguin Books (Reprint, 2002).

Friborg, O., Barlaug, D., Martinussen, M., Rosenvinge, J. H., \& Hjemdal, O. (2005). Resilience in relation to personality and intelligence. International Journal of Methods in Psychiatric Research, 14(1), 29-42. https://doi.org/10.1002/cpp.488

Gable, S. L., \& Haidt, J. (2005). What (and why) is positive psychology? Review of General Psychology, 9(2), 103-110. https://doi.org/10.1037/1089-2680.9.2.103

Gülbahçe, A., \& Özkurt, S. (2016). Analysis of empathic tendencies and empathic skills of prospective students of program of guidance and psychological counseling according to certain variables. Adnan Menderes University Journal of the Faculty of Education, 7(1), 1-15.

Hefferon, H., \& Boniwell, I. (2014). Positive psychology theory, research and practice. (T. Doğan, Trans. Ed.). Nobel Publishing.

Hoşoğlu, R., Kodaz, A. F., Bingöl, T. Y., \& Batık, M. V. (2018). The resilient levels of preservice teachers. International Journal of Society Researches, 8(14), 217-239. https://doi: 10.26466/opus.405751

Houston, D. M., Mckeee, K. L., Carroll, L., \& Marsh, H. (1998). Using humor to promote psychological well-being in residential homes for older people. Aging and Mental Health, 2(4), 328-332. https://doi.org/10.1080/13607869856588 
İlhan, T. (2005). A model of humor styles based on subjective well-being [Unpublished master's thesis]. Gazi University.

Karacaoğlu, K., \& Köktaş, G. (2016). The mediating role of optimism on the relationship between psychological resilience and psychological well-being: A research on hospital employee. The Journal of Human and Work, 3(2), 119-127. https://doi.org/10.18394/iid.20391

Karagöz, Y. (2016). SPSS 23 and AMOS 23 applied statistical analysis. Nobel Academic Publishing.

Karaırmak, Ö., \& Siviş, R. (2008). Transition from modernism to postmodernism and positive psychology. Turkish Psychological Counseling and Guidance Journal, 3(30), 102-115.

Karaırmak, Ö., \& Siviş Çetinkaya, R. (2011). The effect of self-esteem and locus of control on resilience: The mediating role of affects. Turkish Psychological Counseling and Guidance Journal, 4(35), 30-41.

Karasar, N. (2005). Scientific research method: Concepts, principles and techniques. Nobel Publishing.

Kesler, K. D. (1991). Burnout: A multimodal approach to assessment and resolution. Elementary School Guidance \& Counseling, 24(4), 303-311.

Keyes, C. L., \& Annas, J. (2009). Feeling good and functioning well: Distinctive concepts in ancient philosophy and contemporary science. The Journal of Positive Psychology, 4(3), 197-201. https://doi.org/10.1080/17439760902844228

Keyes, C. L., Shmotkin, D., \& Ryff, C. D. (2002). Optimizing well-being: The empirical encounter of two traditions. Journal of Personality and Social Psychology, 82(6), 1007-1022. https://doi.org/10.1037/0022-3514.82.6.1007

Kline, R. B. (2015). Principles and practice of structural equation modeling (4th ed.). Guilford Publications.

Kobasa, S. C. (1979). Stressful life events, personality, and health: An inquiry into hardiness. Journal of Personality and Social Psychology, 37(1), 1-11. https://doi.org/10.1037/0022-3514.37.1.1

Kolburan, Ş. G., Eker, E., \& Akdeniz, B. (2019). Evaluation of relationship between cognitive flexibility and humor styles. The Turkish Adaptation Study of the Militant Extremist Mindset, 16(1), 1-13. https://doi.org/10.5336/forensic.2018-62253

Kosaka, M. (1996). Relationship between hardiness and psychological stressresponse. Journal of Performance Studies, 3, 35-40.

Kuiper, N. A. (2012). Humor and resiliency: Towards a process model of coping and growth. Europe's Journal of Psychology, 8(3), 475-491. http://doi.org/10.23668/psycharchives. 1337

Kuiper, N. A., \& Martin, H. (2010).ls sense of humor a positive personality characteristics? The sense of humor: Explorations of a Personality Characteristic, 3, 159. https://doi.org/10.1515/9783110804607-009

Kuiper, N. A., \& McHale, N. (2009). Humor styles as mediators between selfevaluative standards and psychological well-being. The Journal of Psychology, 143(4), 359-376. https://doi.org/10.3200/JRLP.143.4.359-376 
Kuyumcu, B. (2013). The predictive power of university students' positive-negative moods in their psychological wellbeing. Journal of Theoretical Educational Science, 6(1), 62-76.

Lefcourt, H. M. (2001). Humor: The psychology of living buoyantly. Kluwer Academic Publisher.

Lefcourt, H. M., \& Martin, R. A. (1986). Humor and life stress: antidote to adversity. Springer.

Leiner, D. J. (2014). Convenience samples from online respondent pools: A case study of the SoSci Panel. International Journal of Internet Science, 20(5), 1-18. https://doi: 10.5771/2192-4007-2016-4-36769-134

Luthans, F., Avey, J. B., Avolio, B. J., Norman, S. M., \& Combs, G. M. (2006). Psychological capital development: Toward a micro-intervention. Journal of Organizational Behavior: The International Journal of Industrial, Occupational and Organizational Psychology and Behavior, 27(3), 387-393. https://doi.org/10.1002/job.373

Maiolino, N., \& Kuiper, N. (2016). Examining the impact of a brief humor exercise on psychological well-being. Translational Issues in Psychological Science, 2(1), 413. https://doi.org/10.1037/tps0000065

Malkoç, A., \& Yalçın, İ. (2015). Relationships among resilience, social support, coping, and psychological well-being among university students. Turkish Psychological Counseling and Guidance Journal, 5(43), 35-43.

Martin, R. A. (1998). Approaches to the sense of humor: A historical view. W. Ruch, (Ed.) The sense of humor. Mouton de Gruyter.

Martin, R. A. (2001). Humor, laughter, and physical health: Methodological issues and research findings. Psychological Bulletin, 127(4), 504-519. https://doi.org/10.1037/0033-2909.127.4.504

Martin, R. A., \& Ford, T. (2007). The psychology of humor: An integrative approach (2th ed.). Academic Press.

Martin, R. A., \& Lefcourt, H. M. (1983). Sense of humor as a moderator of the relation between stressors and moods. Journal of Personality and Social Psychology, 45(6), 1313-1324. https://doi.org/10.1037/0022-3514.45.6.1313

Maslow, A. (1954). Motivation and personality. Random House.

May, R. (1953). Man's Search for Himself. Random House.

Meydan, C., \& Şeşen, H. (2015). Structural Equation Model AMOS Applications (2th ed.). Detay Publishing.

Moran, C. C., \& Hughes, L. P. (2006). Coping with stress: Social work students and humor. Social Work Education, 25(5), 501-517. https://doi.org/10.1080/02615470600738890

Olsson, C. A., Bond, L., Burns, J. M., Vella-Brodrick, D. A., \& Sawyer, S. M. (2003). Adolescent resilience: A concept analyses. Journal of Adolescence, 26(1), 1-11. https://doi.org/10.1016/S0140-1971(02)00118-5 
Öz, F., \& Bahadır Yılmaz, E. (2009). A significant concept in protecting mental health: resilience. Hacettepe University Faculty of Health Sciences Nursing Journal, 16(3), 82-89.

Özbay, Y., Palanc1, M., Kandemir, M., \& Çakır, O. (2012). Predicting subjective wellbeing of university students by emotional regulation, humor, social self-efficacy and coping behaviors. Turkish Journal of Educational Sciences, 10(2), 325-345.

Özdolap, M. (2015). The relationship between humor styles and psychological symptoms [Unpublished master's thesis]. Bilim University.

Pidgeon, A. M., \& Keye, M. (2014). Relationship between resilience, mindfulness, and psychological well-being in university students. International Journal of Liberal Arts and Social Science, 2(5), 27-32.

Richardson, G. E. (2002). The met theory of resilience and resiliency. Journal of Clinical Psychology, 58(3), 307-321. https://doi.org/10.1002/jclp.10020

Rogers, C. R. (1961). On becoming a person. Houghton Mifflin.

Ruch, W. (1998). The sense of humor: A new look at an old concept. W. Ruch(Ed.), The sense of humor. Mouton de Gruyter.

Rutter, M. (1999). Resilience concepts and findings: Implications for family therapy. Journal of Family Therapy, 21(2), 119-144. https://doi.org/10.1111/14676427.00108

Ryan, R. M., \& Deci, E. L. (2001). On happiness and human potentials: A review of research on hedonic and eudemonic well-being. Annual Review of Psychology, 52, 141-166. https://doi.org/10.1146/annurev.psych.52.1.141

Ryff, C. D. (1989). Happiness is everything, or is it? Explorations on the meaning of psychological well-being. Journal of Personality and Social Psychology, 57(6), 1069-1081. https://doi:10.1037/0022-3514.857.6.1069

Ryff, C. D., \& Keyes, C. L. M. (1995). The structure of psychological well-being revisited. Journal of Personality and Social Psychology, 69, 719-727. https://doi.org/10.1037/0022-3514.69.4.719

Ryff, C. D., Love, G. D., Essex, M. J., \& Singer, B. (1998). Resilience in adulthood and later life. Handbook of Aging and Mental Health. Springer.

Ryff, C. D., Magee, W. J., Kling, K. C., \& Wing, E. H. (1999). Forging macro-micro linkages in the study of psychological well-being. In C. D. Ryff \& V. W. Marshall (Eds.) The Self and Society in Aging Processes (pp.247-274). Springer Publishing Company.

Ryff, C. D., \& Singer, B. (2003). Flourishing under fire: Resilience as a prototype of challenged thriving. In C. Keyes \& J. Haidt (Eds.), Flourishing: Positive psychology and tile life well-lived(pp.15-36). American Psychological Association.

Satıc1, S. A., \& Deniz, M. E. (2017). Coping with humor and well-being: Examining the mediating role of resilience and optimism. Elementary Education Online, 16(3), 1343-1356. https://doi.org/10.17051/ilkonline.2017.330262

Saunders, M., Lewis, P., \& Thornhill, A. (2012). Research methods for business students. Pearson Education.

Seligman, M. E. (2002). Positive psychology, positive prevention, and positive therapy. Handbook of Positive Psychology, 2, 3-12. 
Seligman, M. E., \& Csikszentmihalyi, M. (2014). Flow and the foundations of positive psychology. Springer.

Sheldon, K. M., \& King, L. (2001). Why positive psychology is necessary. American psychologist, 56(3), 216-263. https://doi.org/10.1037/0003-066X.56.3.216

Sherman, L. W. (1988). Humor and social distance in elementary school children. Humor: International Journal of Humor Research, 1(4), 389-404. https://doi.org/10.1515/humr.1988.1.4.389

Şimşek, H., \& Tanaydın, D. (2002). Parent involvement in primary education: teacherparent-psychological counselor triangle. Elementary Education Online, 1(1), 12-16.

Şimşek, Ö. F. (2007). Introduction to structural equation modeling, basic principles and LISREL Applications. Ekinoks Publishing.

Souri, H., \& Hasanirad, T. (2011). Relationship between resilience, optimism and psychological well-being in students of medicine. Procedia-Social and Behavioral Sciences, 30(2), 1541-1544. https://doi.org/10.1016/j.sbspro.2011.10.299

Stewart, M., Reid, G., \& Mangham, C. (1997). Fostering children's resilience. Journal of Pediatric Nursing, 12(1), 21-31. https://doi.org/10.1016/S0882-5963(97)80018-8

Tabachnick, B. G., \& Fidell, L. S. (2015). Use of multivariate statistics. (M. Baloğlu, Trans., Ed.). Nobel Publishing.

Telef, B. B. (2013). The adaptation of psychological well-being into Turkish: A validity and reliability study. Hacettepe University Journal of Education, 28(3), 374-384.

Terzi, Ş. (2005). Psychological hardiness model relating to subjective well-being [Unpublished doctoral dissertation]. Gazi University.

Thorson, J. A., Powell, F. C., Sarmany-Schuller, I., \& Hampes, W. P. (1997). Psychological health and sense of humor. Journal of Clinical Psychology, 53(6), 605-619. https://doi.org/10.1002/(SICI)1097

Turkish Language Association. (2020). TLA current Turkish dictionary, [http://tdk.org.tr]. Date of access: 21.11.2020.

Wagnild, G. (2009). A review of the Resilience Scale. Journal of nursing measurement, 17(2), 105-113. https://doi: 10.1891/1061-3749.17.2.105

Wothke, W. (2010). Introduction to structural equation modeling course notes. Carolina del Norte: SAS Institute Inc.

Yerlikaya, E. E. (2003). The adaptation of humor styles questionnaire into Turkish language [Unpublished master's thesis]. Çukurova University.

Yerlikaya, E. E. (2009). The relationship between humor styles and perceived stress, anxiety and depression of college students [Unpublished doctoral thesis]. Çukurova University. 